\title{
Measuring change in academic libraries: NCES starts something new
}

For many years, the National Center for Education Statistics (NCES) has conclucted a biennial Academic Libraries Survey (ALS) as part of the Integrated Postsecondary Education Data Survey (IPEDS). Datal tables were published but no comparative reports were done. That situation changed this June with the publication of The Status of Academic Libraries in the United States: Results from the 1990 and 1992 Academic Library Surveys (NCES 97-413). This 28-page report, prepared under contract by the American Institutes for Research. compares ALS data over time (1990-92) and displays data using the Carnegie classification.

The report focuses on the following seven indicators:

\section{Library Staff}

- Library Staff/Student Ratios

- Library Staff/Instructions Faculty Rátios

\section{Books, Serial Backfiles, and Other Print} Materials

- Total Volumes Held

- Total Volumes Held per FTE Student

- Total Library Expenditures

- Library Share of Institutional Budgets

- Expenditures per FTE Student

These seven were chosen because they are important but also because data were available for both 1990 and 1992 from at least 70 percent of the IPEDS universe. Only institutions responding in both years were in-

annual research program at the ALA Annual Conference in Washington, D.C. in June 1998.

Use this opportunity to share with your colleagues recent research or works in progress that address significant issues to science and technology librarianship in its broadest sense.

Proposals will be selected through a blind review process on the basis of timeliness, evidence of scholarship, and relevance to science and technology assembly.

An abstract not exceeding 250 words should convey the title and purpose of the project, its scope, methodology, conclusions, and relevance to science and technology librarianship. Priority will be given to papers that indi- cluded in the analysis. Values for 1992 are shown together with percentage change in those values since 1990 .

Given the present rate of change in the academic library community, it is hard to get excited about statistics from 1990 and 1992, despite the effective way they are presented in this report. It is an important milestone, however, in that it is the first publication on academic libraries from NCES that compares data from different years and uses the Carnegie classification to organize it. Work is already underway on another report, this time by Mathematica, that will update those seven indicators using data from the 1994 ALS, and will also do additional analysis of 1994 data. John Minter Associates has already used a preliminary file of 1994 data from the individual states to produce several publications. Check the John Minter Associates Web site: http://www.edmin.con//jna; or phone (800) 444-8110.

Note: A few copies of this report are available from the author of this article (mlynch@ala.org). Otherwise they are available from: New Orders, Superintendent of Documents, P.O. Box 371954, Pittshurgh, PA 15250-7954. The stock number is $065-000-01033-0$ and the price is $\$ 4$. You may place credit card orders by fax at (202) 512-2250. This product is also available at http://www.ed.gov/NCES/pubs97/ 97413.html-Mary Jo Lynch, ALA Office for Research and Statistics

cate research analyses, either quantitative or qualitative.

Deadline for submission: November 21 1997. Papers will be selected at the ALA Midwinter Meeting

Authors of accepted proposals should be committed to providing a 30-minute presentation at the 1998 ALA Annual Conference. Flectronic publication of papers through ACRL/STS is an option.

Submit abstract (e-mail preferred) with name, institution, phone, fax, and e-mail address to: Tamera Lee, Vet. Medical Library, 101 Greene Hall, Aul)urn University. AL 368495606; phone: (334) 844-1749; fax: (334) 8841758; e-mail: TammyLee@Lib.Auburn.Edu. 